\title{
Questions about "No evidence on the effectiveness of oral splints for the management of temporomandibular joint dysfunction pain in both short and long-term follow-up systematic reviews and meta-analysis studies"
}

\author{
Matheus Souza Campos Costa ${ }^{1}$, Sandy Maria da Silva Costa ${ }^{1}$, Nicole Rosa de Freitas ${ }^{1}$, \\ Luísa Belluco Guerrini ${ }^{1}$, Caio Sousa Ferraz ${ }^{2}$, Ana Lúcia Pompéia Fraga de Almeida ${ }^{1,3}$ \\ ${ }^{1}$ Department of Prosthodontics and Periodontics, Bauru School of Dentistry, University of São Paulo, Bauru, \\ ${ }^{2}$ Department of Orthodontics, Bahia School of Dentistry, Federal University of Bahia, Salvador, \\ ${ }^{3}$ Hospital for the Rehabilitation of Craniofacial Anomalies, University of São Paulo, Bauru, Brazil
}

To the Editor,

This letter is related to the article "No evidence on the effectiveness of oral splints for the management of temporomandibular joint dysfunction pain in both short and long-term follow-up systematic reviews and meta-analysis studies", by Fouda $^{1}$, published in the issue of April 2020 of the Journal of the Korean Association of Oral and Maxillofacial Surgeons. Initially, we congratulate the author and the journal for the publication.

The theme of the referred study awaked our deepest interest in reading. However, caught our attention by the fact that a systematic review was carried out by only one author, since the participation of another person(s) in the development of the study was not reported in the structure of the article. Was there any specific reason for such a choice? Still on the composition of a team for the preparation of a systematic review, the Cochrane Collaboration, for example, addresses the broad defense that exists about the need for at least two people to work independently, both in the selection of studies observing the eligibility criteria, as well as data extraction from selected studies ${ }^{2}$. Regarding the selection of studies, the lists of included studies prepared by the two reviewers are then compared and the differences resolved, either through discus-

\section{Matheus Souza Campos Costa}

Department of Prosthodontics and Periodontics, Bauru School of Dentistry, University of São Paulo, Alameda Doutor Octávio Pinheiro Brisolla 9-75, Vila Universitária, Bauru, São Paulo 17012-901, Brazil

TEL: +55-73-991475005 FAX: +55-77-3426-1160

E-mail: matheuscampos8@usp.br

ORCID: https://orcid.org/0000-0003-4075-0183

(c) This is an open-access article distributed under the terms of the Creative Commons Attribution Non-Commercial License (http://creativecommons.org/ licenses/by-nc/4.0/), which permits unrestricted non-commercial use, distribution, and reproduction in any medium, provided the original work is properly cited.

Copyright (C) 2020 The Korean Association of Oral and Maxillofacial Surgeons. All rights reserved. sion or involving a third researcher ${ }^{3}$.

It is also worth mentioning that, for the preparation of a systematic review, the construction of a research question is oriented, encompassing four items represented by the acronym PICO (Population, Interventions, Comparators, Outcomes) ${ }^{2}$. According to PRISMA (Preferred Reporting Items for Systematic Reviews and Meta-Analyses), this question it must be presented explicitly in the introduction of the systematic review ${ }^{4}$.

Another fact that caught our attention was a study ${ }^{5}$ classified as of intermediate follow-up period (three months), included in the meta-analysis as a long-term evaluation (six months or one year). Was there any reason for this option?

\section{ORCID}

Matheus Souza Campos Costa, https://orcid.org/00000003-4075-0183

Sandy Maria da Silva Costa, https://orcid.org/0000-00024513-8981

Nicole Rosa de Freitas, https://orcid.org/0000-0001-5494-1189

Luísa Belluco Guerrini, https://orcid.org/0000-0002-5673-595X

Caio Sousa Ferraz, https://orcid.org/0000-0003-3764-5585

Ana Lúcia Pompéia Fraga de Almeida, https://orcid.org/00000003-2288-9624

\section{Authors' Contributions}

M.S.C.C. participated in writing - original draft preparation. S.M.S.C., N.R.F., L.B.G., C.S.F., and A.L.P.F.A. participated in writing - review and editing. All authors read and approved the final manuscript. 


\section{Conflict of Interest}

No potential conflict of interest relevant to this article was reported.

\section{References}

1. Fouda AAH. No evidence on the effectiveness of oral splints for the management of temporomandibular joint dysfunction pain in both short and long-term follow-up systematic reviews and metaanalysis studies. J Korean Assoc Oral Maxillofac Surg 2020;46:8798. https://doi.org/10.5125/jkaoms.2020.46.2.87

2. Higgins JPT, Thomas J, Chandler J, Cumpston M, Li T, Page MJ, eds. Cochrane handbook for systematic reviews of interventions. 2nd ed. Hoboken: Wiley-Blackwell; 2019.

3. Charrois TL. Systematic reviews: what do you need to know to get started? Can J Hosp Pharm 2015;68:144-8. https://doi.org/10.4212/ cjhp.v68i2.1440
4. Moher D, Shamseer L, Clarke M, Ghersi D, Liberati A, Petticrew M, et al.; PRISMA-P Group. Preferred reporting items for systematic review and meta-analysis protocols (PRISMA-P) 2015 statement. Syst Rev 2015;4:1. https://doi.org/10.1186/2046-4053-4-1

5. Conti PCR, Corrêa ASM, Lauris JRP, Stuginski-Barbosa J. Management of painful temporomandibular joint clicking with different intraoral devices and counseling: a controlled study. J Appl Oral Sci 2015;23:529-35. https://doi.org/10.1590/1678-775720140438

How to cite this article: Costa MSC, Costa SMS, Freitas NR, Guerrini LB, Ferraz CS, Almeida ALPF. Questions about "No evidence on the effectiveness of oral splints for the management of temporomandibular joint dysfunction pain in both short and longterm follow-up systematic reviews and meta-analysis studies". J Korean Assoc Oral Maxillofac Surg 2020;46:367-368. https://doi. org/10.5125/jkaoms.2020.46.5.367 